\title{
Microstructure of kajmak skin layer made during kajmak production
}

\author{
Mira Radovanovic*, Aleksandar Nedeljkovic, \\ Jelena Miocinovic, Vladimir Pavlovic, Predrag Pudja
}

\author{
University of Belgrade, Faculty of Agriculture, Department of Animal Source Food Technology, \\ Nemanjina 6, 11080 Belgrade, Serbia \\ ${ }^{*}$ Corresponding author: m.radovanovic@agrif.bg.ac.rs
}

\section{Abstract}

Kajmak is a unique dairy product with a long tradition in Balkan countries and the Middle East. Kajmak skin layers are formed during 60 minutes of kajmak production, influencing the quality and determining the structure of the final product. The influence of milk composition and heat treatments (75-95 $\left.{ }^{\circ} \mathrm{C} / 5 \mathrm{~min}\right)$ on the composition, microstructure and protein distribution of kajmak skin layers was investigated in this study. Microstructure was determined using scanning electron microscopy (SEM), while the distribution of protein fractions was studied by SDS PAGE in reducing and non-reducing conditions. Kajmak skin layers obtained from milk treated at common intense heat regime were characterized with $\beta$-LG and a-LA mainly as disulfide-linked complexes, while lower temperature $\left(75^{\circ} \mathrm{C}\right)$ caused the presence of whey proteins in dominantly individual form. More severe treatments $\left(85^{\circ} \mathrm{C}, 90^{\circ} \mathrm{C}\right.$ and $\left.95^{\circ} \mathrm{C}\right)$ caused the full involvement of $\beta$-LG in the complexes, since a certain amount of a-LA was found as a monomer. The kajmak skin layer composition, severity of the applied milk heat treatment and the linked whey proteins exhibited a very strong influence on kajmak skin layer microstructure. The microstructure of kajmak skin layer with a low fat content and fat/protein (F/P) ratio was characterized by a compact structure with a dense protein matrix. High fat content and F/P ratio resulted in a dispersive form of the stretched protein network. Kajmak skin layers produced from milk with added whey proteins were characterized by fibrous, thread-like segments, due to the incorporated denatured whey proteins, especially linked $\beta$-LG.

Key words: microstructure, kajmak, kajmak skin layer, milk fat, milk proteins 


\section{Introduction}

Kajmak is a dairy product primarily composed of milk fat and proteins. It has a very specific production procedure and mechanism of its formation, due to which kajmak stands out from other dairy products. According to its composition and characteristics, kajmak is classified as somewhere between cheese and butter (Pudja et al., 2008). It is traditionally produced in the Balkans, the Asia Minor and the Near East (Akalin et al., 2006; Cakmakci and Hayaloglu, 2011). In Serbia, kajmak is either used fresh, immediately after production and salting, or mature after a substantial maturation process (Djerovski et al., 2006).

Kajmak production is characterized by a long process that begins with slowly pouring hot milk into shallow vessels without foaming. Then, milk cooling begins spontaneously by the surrounding air during 12 or more hours (Dozet et al., 1996). The traditional kajmak production procedure is based on kajmak skin layer formation on the top of the milk, as a result of both surface phenomena and water evaporation (Pudja et al., 2006).

Kajmak formation process can be split into two phases: the hot and the cold phase. At the beginning of the hot phase that lasts for 60 minutes, milk fat and proteins are concentrated on the top of the milk, forming a thin matrix layer. Over time, the matrix on the top gets thicker, resulting in the formation of kajmak skin layer at the end of the hot phase of kajmak production. During the cold phase, kajmak skin layer grows, due to the incorporation of milk components, mostly milk fat. The top part of the end-product has a significantly higher protein content (cca $7 \%$ ) compared to the bottom part of kajmak (cca 2 \%) (Radovanovic et al., 2013). The kajmak formation process and quality are affected by a number of factors, such as milk composition and heat treatment (Pudja et al., 2005a, b; Radovanovic et al., 2012a), ambient air parameters (temperature and relative humidity), and air circulation dynamics (Pudja et al., 2008; Ecim-Djuric et al., 2012, 2013, 2017).

Severe and long lasting milk heat treatment applied in kajmak production induces strong changes on milk proteins, such as the denaturation of whey proteins (Lyster, 1970; Dannenberg and KessIer, 1988; Anema and McKenna, 1996), formation of milk protein coaggregates (Corredig and Dalgleish, 1999; Anema and Li, 2003; Petit et al., 2012), and reactions of denatured whey proteins with milk fat globule membrane proteins, MFGM (Corredig and Dalgleish, 1996b; Ye et al., 2004). Whey proteins have a significant role in the kajmak formation process (Radovanovic et al., 2012b). $\beta$-lactoglobulin ( $\beta$-LG) and a-lactalbumin (a-LA) are present in the product mainly as disulfide linked complexes (Atamer et al., 2016). Adding whey proteins to milk for kajmak production increases the level of bound whey proteins, resulting in increased kajmak yield (Radovanovic et al., 2012b).

Scanning electron microscopy (SEM) was used to study the microstructure of cheese and a number of other dairy products, however, the microstructure of kajmak traditionally produced in the Balkans has not been examined until now. According to Radovanovic et al. (2014), the microstructure of kajmak skin layer is strongly affected by its composition.

Kajmak skin layer formation was examined after the first 60 minutes because the evaporation process, i.e. mass and energy transfers, are the most intensive during the first 10 minutes, after which time they gradually slow down, and sixty minutes into the process become practically negligible (Ecim-Djuric et al., 2013). Also, the composition and particularly the protein content of kajmak skin layer were similar to the composition of the top part of the end-product, which suggests that the hot phase of kajmak production may play a significant role in the structure formation of the end-product.

This study reviews the influence of milk heat treatment and milk composition on the microstructure of kajmak skin layer formed during the first 60 minutes of the kajmak formation process.

\section{Materials and methods}

\section{Kajmak skin layer production}

The experiments were designed in two series: the influence of the milk heat treatment (T Series) and milk composition (S Series) on the composition and microstructure of kajmak skin layer.

In T Series, milk samples with $4 \%$ fat and 3.4\% proteins were heated at different thermal regimes (Table 1). 
TABLE 1. Milk heat treatment used in the preparation of T Series kajmak skin layer samples

\begin{tabular}{l|l}
\hline Skin layer & Heat treatment of milk, ${ }^{\circ}$ C/time $($ min. $)$ \\
\hline T1 & $75 / 5$ \\
\hline T2 & $80 / 5$ \\
\hline T3 & $85 / 5$ \\
\hline T4 & $90 / 5$ \\
\hline T5 & $95 / 5$ \\
\hline
\end{tabular}

TABLE 2. The milk composition used in preparation of the $\mathrm{S}$ Series kajmak skin layer samples

\begin{tabular}{l|l|l|l}
\hline $\begin{array}{l}\text { Skin } \\
\text { layer }\end{array}$ & $\begin{array}{l}\text { Fat, } \\
\%\end{array}$ & $\begin{array}{l}\text { Protein, } \\
\%\end{array}$ & $\begin{array}{l}\text { Addition of whey } \\
\text { proteins, \% }\end{array}$ \\
\hline C & 4.0 & 3.4 & $/$ \\
\hline S1 & 8.0 & 3.4 & $/$ \\
\hline S2 & 4.0 & 5.0 & $/$ \\
\hline S3 & 4.0 & 3.4 & 0.6 \\
\hline S4 & 8.0 & 5.0 & 0.6 \\
\hline
\end{tabular}

In the S Series, milk with the identical composition (4 \% fat, $3.4 \%$ proteins) was used as a control sample $(C)$, while the composition of other samples varied from $4-8 \%$ of fat and $3.4-5 \%$ of proteins (Table 2). Whey protein concentration of samples S3 and S4 was increased by adding a whey protein concentrate. Milk samples of S Series were subjected to two stages of heat treatment, $85^{\circ} \mathrm{C}$ for 10 minutes (first stage) and $95^{\circ} \mathrm{C}$ for 10 minutes (second stage). The applied heat treatment is typically used in the traditional, homemade kajmak production procedure.

Raw milk (3 kg per batch) used for kajmak skin layer production was obtained from the dairy plant "Granice" (Mladenovac, Serbia). The composition of milk samples was standardised by adding: the protein powder concentrate (Promilk 852 A2, Ingredia, France); unhomogenized cream with $36 \%$ fat (PIK Zemun, Serbia) and the whey protein powder concentrate Textrion Progel 800 (DMV International, Holland).

Control and standardized milk samples were heat treated and then poured into round vessels, where kajmak skin layer formation took place (dimensions $0.24 \times 0.07 \mathrm{~m}$ ) for over 60 minutes at room temperatures/conditions such as the ones typically used in traditional kajmak production. Kajmak skin layers were collected and analyzed after a 5 min. drainage on the grid. The experiments were carried out in triplicate.

\section{Kajmak skin layer composition}

Kajmak skin layer samples were analysed for fat by the Van Gulik method (IDF, 1986) and the nitrogen content by the Kjeldahl method (IDF, 2002). The protein content was calculated as the nitrogen content multiplied by 6.38 , while the fat/protein ratio $(F / P)$ was calculated based on the fat and protein content. All analyses were carried out at least in duplicate.

\section{SDS PAGE electrophoresis}

Kajmak skin layer samples were analysed by a sodium dodecyl sulfate polyacrylamide gel electrophoresis (SDS-PAGE) in reducing (SDS-R) and non-reducing conditions (SDS-NR), using the method by Laemmli (1970). The resolving gel contained $15 \%$ acrylamide in $0.375 \mathrm{~mol} \mathrm{dm}^{-3} \mathrm{Tris} / \mathrm{HCl}$ buffer at $\mathrm{pH} 8.85$, while the stacking gel contained $4 \%$ acrylamide in $0.125 \mathrm{~mol} \mathrm{dm}^{-3}$ buffer at $\mathrm{pH} 6.80$. Kajmak skin layer samples (1.0 g) were dispersed in $5.0 \mathrm{~mL}$ resolving buffer $(0.125 \mathrm{M}$ Tris/ $\mathrm{HCl}$ buffer at $\mathrm{pH} 8.00$, containing $4 \%$ (wt/v) SDS) and heated at $95^{\circ} \mathrm{C}$ for 3 minutes. Centrifugal supernatants were diluted with sample buffer $(0.055 \mathrm{M}$ Tris $/ \mathrm{HCl}$ buffer at pH 6.80 containing $4 \%(\mathrm{wt} / \mathrm{v})$ SDS $10 \%(\mathrm{v} / \mathrm{v})$ glycerol and $0.003 \%$ (wt/v) bromophenol blue) in order to achieve a protein concentration of $3 \mu \mathrm{g} / \mu \mathrm{L}$. To prepare samples in SDS-R condition, $(3.6 \% \mathrm{v} / \mathrm{v})$ and $2 \%(v / v) \beta$-mercaptoethanol was added into the resolving and sample buffer, respectively. The prepared samples were boiled for 5 minutes. The sample amount of $5 \mu \mathrm{L}$ was loaded onto the gel.

Electrophoresis was performed using the vertical electrophoretic unit type TV200YK twin-plate, associated with the source voltage of EV202 (Consort, Belgium). Electrophoresis was done under the following conditions: I const. $=80 \mathrm{~mA}$, Umax. $300 \mathrm{~V}$. The gels were run in a $\mathrm{pH} 8.30$ running buffer 
(0.025 mol dm-3 Tris, $0.192 \mathrm{~mol} \mathrm{dm}^{-3}$ glycine and $0.1 \%$ (wt/v) SDS) for 75 minutes. Gel staining was performed in $0.23 \%$ solution of Coomassie Blue R-250, containing $3.9 \%(w t / v)$ TCA, $6 \%$ (v/v) acetic acid and $17 \%(\mathrm{v} / \mathrm{v})$ methanol, during 90 minutes. Gels were destained by $18 \%(\mathrm{v} / \mathrm{v})$ ethanol and $8 \%$ (v/v) acetic acid solution during $24 \mathrm{~h}$. Densitometric analyses were performed by scanning the gels using the Image Scaner Epson Expression 10000XL (Epson, Japan) with Image Quant software (version 5.2; 1999; Molecular Dynamics, Inc.). The molecular weight standards were: recombinant SDS PAGE protein marker $(10,000-150,000)$ with protein sizes of 10,000; 20,000; 30,000; 40,000; 60,000; 80,000; 100,000 and 150,000 (Serva Electrophoresis, Germany); and protein marker $(14,200-66,000)$ with proteins: bovine albumin (66,000), egg albumin $(45,000)$, rabbit muscle glyceraldehyde-3-phosphate dehydrogenase $(36,000)$, bovine carbonic anhydrase (29,000), bovine pancreas trypsinogen $(24,000)$, soybean trypsin inhibitor $(20,000)$ and a-lactalbumin of bovine milk $(14,200)$ (Sigma, USA).

Distribution of protein fractions was analyzed by the characterization of the protein fractions under reducing and non-reducing conditions in order to identify the presence of disulfide bonds in protein aggregates.

The identified protein fractions were classified into three groups: the high molecular weight fractions (HMWF), the casein fractions (CF) and the major whey protein fractions (MWPF). The MWPF/ CF ratio was calculated. The HMWF group includes protein fractions with less mobility compared to caseins. The CF group, includes $a_{s}, \beta$ - and $k-C N$, while MWPF group includes $\alpha-L A$ and $\beta$-LG.

\section{Scanning Electron Microscopy (SEM)}

After collecting and draining them on the grid, kajmak skin layer samples were cut with a razor blade into strips of $3 \times 3 \times 5 \mathrm{~mm}$ size and prepared according to Joshi et al. (2004). The kajmak skin layer strips were fixed by immersion in a freshly prepared $2.8 \%$ glutaraldehyde, buffered at pH 6.0 with $0.05 \mathrm{M}$ phosphate buffer solution and stored for $24 \mathrm{~h}$ at $4{ }^{\circ} \mathrm{C}$. Samples were dehydrated by subsequent transfer, for 10 minutes in a series of ethanol concentrations (10, 20, 40, 60, 80, 90 and $100 \%$ ), extracted in chloroform for 90 minutes and stored in $100 \%$ ethanol until drying in a critical point carbon dioxide drying apparatus (Critical Point Dryer, CPD 030, BAL-TEC, Scan, Germany). Shortly after, the dried samples were coated with a thin layer of gold by the sputter coater (SCD 005, BAL-TEC). Microstructure examination was done using a JOEL JSM-6390 LV scanning electron microscope operated at 5,000x, 10,000x and 20,000x magnification.

\section{Statistical analysis}

Data were analysed in order to investigate the influence of heat treatment and milk fat and protein levels on the composition of skin layers obtained by using STATISTICA 6.0 (StatSoft, USA) data analysis software. Mean comparisons of the parameters were performed by the LSD-test, with the levels of significance at 0.05 and 0.01 .

\section{Results and discussion}

\section{Kajmak skin layer composition}

The increase of the severity of heat treatment from $75^{\circ} \mathrm{C}$ to both 90 and $95^{\circ} \mathrm{C}$ resulted in a significant $(P<0.01)$ increase in the protein content and a very significant decrease $(P<0.01)$ of the fat content and F/P ratio of kajmak skin layers (Table 3 ).

TABLE 3. Average composition and F/P ratio of kajmak skin layers of $\mathrm{T}$ Series

\begin{tabular}{l|l|l|l}
\hline Skin layer & Fat, \% & Protein, \% & F/P \\
\hline T1 & $53.17^{\mathrm{a} 1 \mathrm{A2}}$ & $8.71^{\mathrm{aA}}$ & $6.17^{\mathrm{aA}}$ \\
\hline $\mathrm{T} 2$ & $52.33^{\mathrm{aA}}$ & $8.97^{\mathrm{bA}}$ & $5.83^{\mathrm{bA}}$ \\
\hline $\mathrm{T} 3$ & $49.67^{\mathrm{bB}}$ & $9.11^{\mathrm{bA}}$ & $5.45^{\mathrm{CB}}$ \\
\hline $\mathrm{T} 4$ & $45.17^{\mathrm{CC}}$ & $9.41^{\mathrm{CB}}$ & $4.80^{\mathrm{dC}}$ \\
\hline T5 & $43.00^{\mathrm{dD}}$ & $10.41^{\mathrm{dC}}$ & $4.13^{\mathrm{eD}}$ \\
\hline
\end{tabular}

1 different letters means within same column significant difference $(P<0.05)$

${ }^{2}$ different letters means within same column indicate significant difference $(\mathrm{P}<0.01)$ 
TABLE 4. Average composition and F/P ratio of kajmak skin layers of S Series

\begin{tabular}{l|l|l|l}
\hline Skin layer & Fat, \% & Protein, \% & F/P \\
\hline C & $58.50^{\mathrm{a} 1 \mathrm{~A} 2}$ & $7.97^{\mathrm{aA}}$ & $7.34^{\mathrm{aA}}$ \\
\hline S1 & $70.55^{\mathrm{bA}}$ & $5.49^{\mathrm{bB}}$ & $12.85^{\mathrm{bB}}$ \\
\hline S2 & $60.30^{\mathrm{aA}}$ & $8.26^{\mathrm{aA}}$ & $7.30^{\mathrm{aA}}$ \\
\hline S3 & $58.67^{\mathrm{aA}}$ & $7.90^{\mathrm{aA}}$ & $7.43^{\mathrm{aA}}$ \\
\hline S4 & $58.50^{\mathrm{aA}}$ & $9.04^{\mathrm{bA}}$ & $6.47^{\mathrm{bA}}$ \\
\hline
\end{tabular}

1 different letters means within same column significant difference $(\mathrm{P}<0.05)$

${ }^{2}$ different letters means within same column indicate significant difference $(P<0.01)$

The composition and F/P ratio of kajmak skin layers obtained from milk with different fat and protein contents are shown in Table 4. The increase of the milk fat content from $4 \%$ to $8 \%$ led to a strong increase in the fat content $(P<0.05)$ and a very strong reduction of the protein content $(\mathrm{P}<0.01)$ in kajmak skin layer samples. At the same time, the increase in the milk protein content from $3.4 \%$ to $5.0 \%$ resulted in a slight increase of the fat content $(P>0.05)$ and an apparent increase of the protein content in kajmak skin layer, but without a statistical significance. The addition of whey proteins to the control sample (4 \% fat, $3.4 \%$ protein) did not affect the fat and protein content of kajmak skin layer.

\section{Characterization of kajmak skin layer protein fractions}

The electrophoretogram of kajmak skin layers from T Series is shown in Figure 1. SDS PAGE showed that the applied milk heat treatments altered the protein profile. The increase of the milk heat treatment severity resulted in an increase of the MWPF/CF ratio (Table 5), having the smallest ratio value in $T 1$ (0.20), which was significantly different to T2 $(P<0.05)$ and very significantly different to samples T3, T4 and T5 $(P<0.01)$. At the same time, increased severity of the milk heat treatment from $85^{\circ} \mathrm{C}$ to $95^{\circ} \mathrm{C}$ induced a small, but statisticaly not significant increase in the MWPF/CF ratio.

The SDS-NR PAGE showed that the presence of $\beta$-LG and a-LA in kajmak skin layers depends on the severity of the applied milk heat treatment (Figure 1). The least severe heat treatment $\left(75^{\circ} \mathrm{C}\right)$ caused the presence of $\beta$-LG in dominantly individual form. More severe heat treatments $\left(85^{\circ} \mathrm{C}, 90^{\circ} \mathrm{C}\right.$ and $\left.95^{\circ} \mathrm{C}\right)$ caused a full incorporation of $\beta$-LG into high molecular weight complexes formed on the disulfide bond basis. The complexes did not include the total amount of $\mathrm{a}-\mathrm{LA}$, which is proved by the presence of a certain amount of a-LA in monomer form found in all kajmak skin layer samples. The incomplete aggregation of a-LA in all skin samples is probably the result of an insufficient duration of the heat treatment of milk necessary for the complete denaturation of a-LA (Corredig and Dalgleish, 1996a; Anema, 2001; Anema and Li, 2003).

The electrophoregram of kajmak skin layers from $\mathrm{S}$ Series is shown in Figure 2, while the distribution of protein fractions is shown in Figure 3. The absence of MWPF in non-reducing conditions, presented in Figure 2, was recorded previously (Radovanovic et al., 2012b). The study found a higher content of HMWF and CF in non-reducing conditions compared to reducing conditions (Figure 3). The increased HMWF content is probably a consequence of a complex formation between disulfide-linked whey proteins among themselves and/or with casein. The highest content of bound whey proteins, as well as MWPF/FC ratio (Table 6), was found in samples fortified with whey proteins.

A few protein fractions in HMWF (mol. weights from 64,000 to 100,000 ) were identified by densitometric analysis under both reducing and non-reducing conditions. In all samples, the fraction of about 68,000 had the prevailing participation, having about $30 \%$ of HMWF in reducing and $50 \%$ in non-reducing conditions (results not shown). 


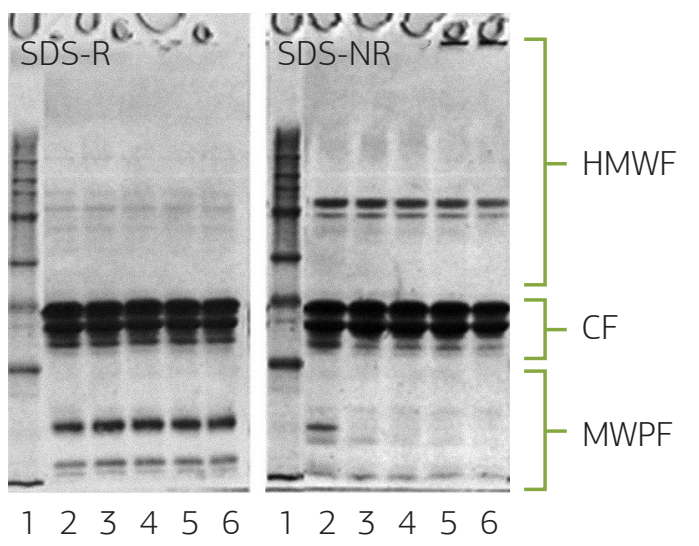

FIGURE 1. SDS electrophoretograms under reducing and nonreducing conditions of kajmak skin layers of T Series: 1 . Standard mol. weights 10,000-150,000; 2-6. Kajmak skin layers (T1-T5)

TABLE 5. MWPF/CF ratio of kajmak skin layers of T Series

\begin{tabular}{l|l|l}
\hline \multirow{2}{*}{$\begin{array}{l}\text { SDS-PAGE } \\
\text { Reducing } \\
\text { condition }\end{array}$} & Skin layer & MWPF/CF \\
\cline { 2 - 3 } & T2 & $0.20^{\mathrm{a} 1 \mathrm{A2}}$ \\
\cline { 2 - 3 } & T3 & $0.23^{\mathrm{bA}}$ \\
\cline { 2 - 3 } & T4 & $0.26^{\mathrm{bB}}$ \\
\cline { 2 - 3 } & T5 & $0.28^{\mathrm{bB}}$ \\
\hline
\end{tabular}

' different letters means within same column significant difference $(P<0.05)$

${ }^{2}$ different letters means within same column indicate significant difference $(P<0.01)$

TABLE 6. MWPF/CF ratio of kajmak skin layers of S Series
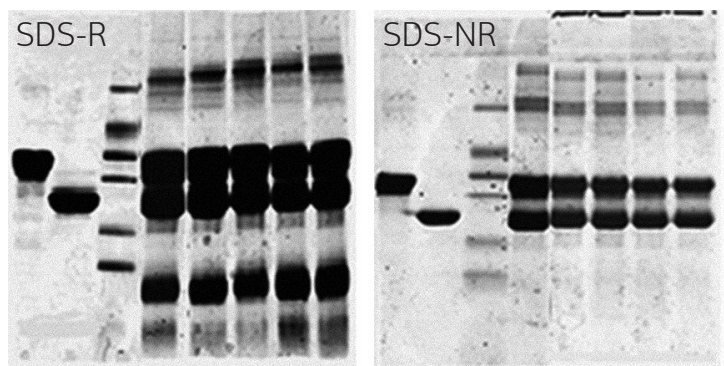

$\begin{array}{llllllllllllllll}1 & 2 & 3 & 4 & 5 & 6 & 7 & 8 & 1 & 2 & 3 & 4 & 5 & 6 & 7 & 8\end{array}$

FIGURE 2. SDS electrophoretograms under reducing and non-reducing conditions of kajmak skin layers of S Series: 1. Standard as-CN; 2. Standard $\beta-C N ; 3$. Standard mol. weight 14,200-66,000; 4-8. C, S1, S2, S3, S4 kajmak skin layers.

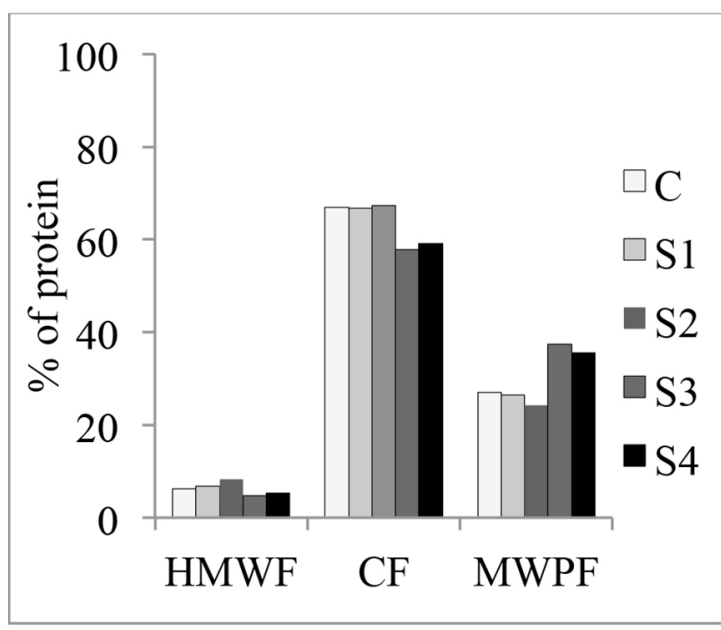

a

\begin{tabular}{l|l|l}
\hline SDS-PAGE & Skin layer & MWPF/CF \\
\hline $\begin{array}{l}\text { Reducing } \\
\text { condition }\end{array}$ & $\mathrm{C}$ & 0.40 \\
\cline { 2 - 3 } & S1 & 0.40 \\
\cline { 2 - 3 } & S2 & 0.36 \\
\cline { 2 - 3 } & S3 & 0.64 \\
\cline { 2 - 3 } & S4 & 0.60 \\
\hline
\end{tabular}

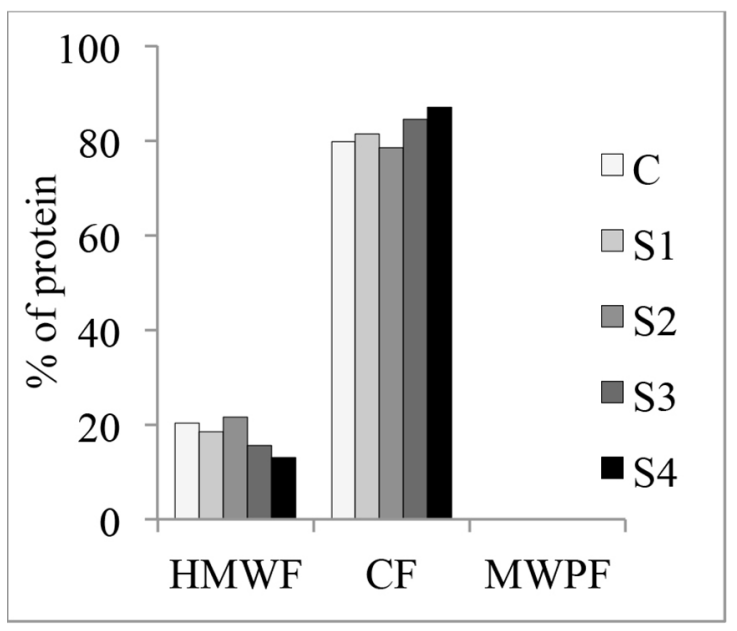

b

FIGURE 3. Distribution of protein fraction groups of kajmak skin layer in reducing (a) and non-reducing conditions (b) 


\section{Microstructure of kajmak skin layers}

The SEM micrographs of kajmak skin layers are shown in Figures 4 and 5. The lower magnifications (2,000x and 5,000x) illustrate the gross structure, especially the porosity of the protein matrix, whereas the higher magnifications (10,000x and 20,000x) provide more details regarding changes at the micellar level.
$\mathrm{T} 1$
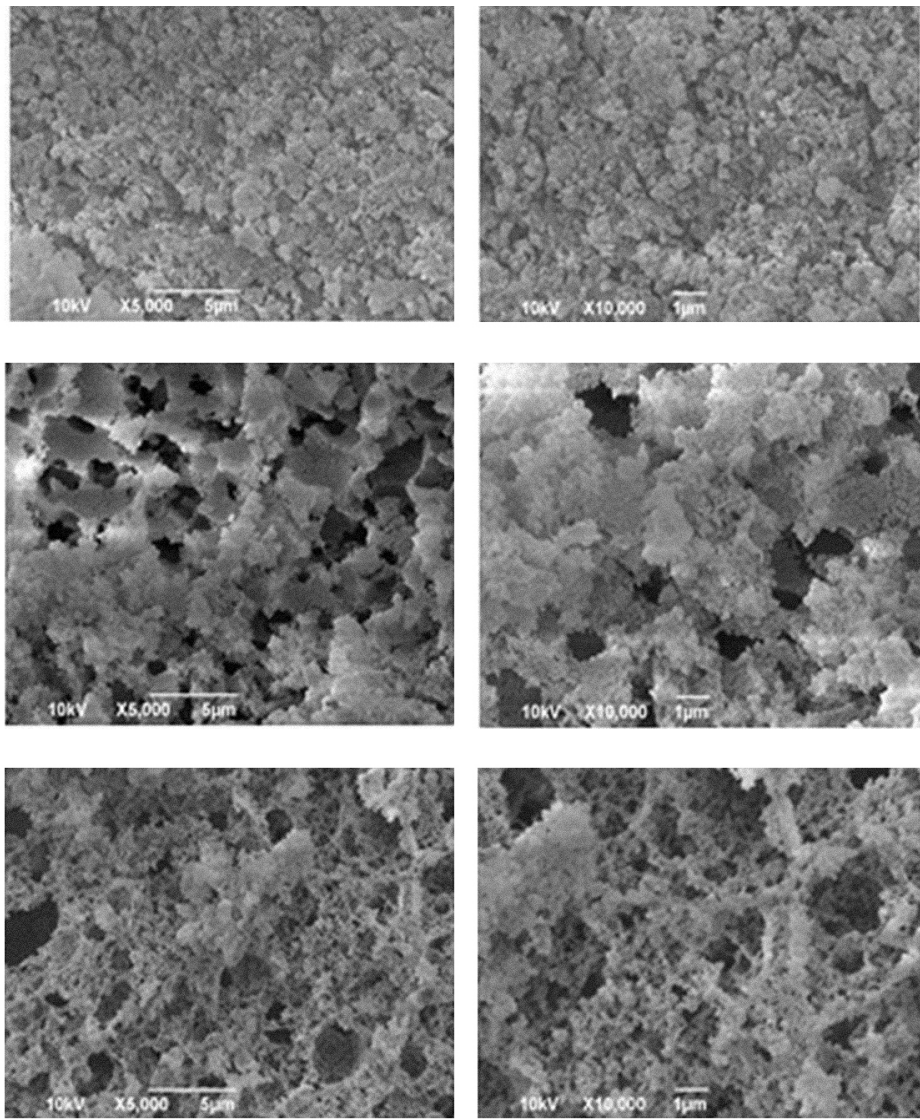

a

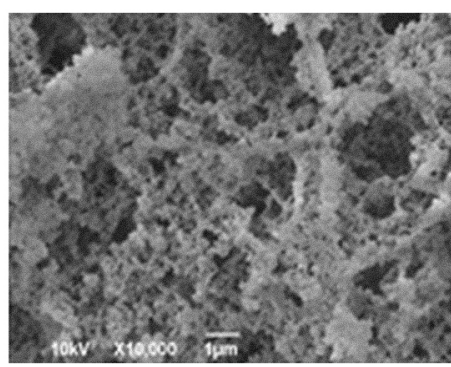

b
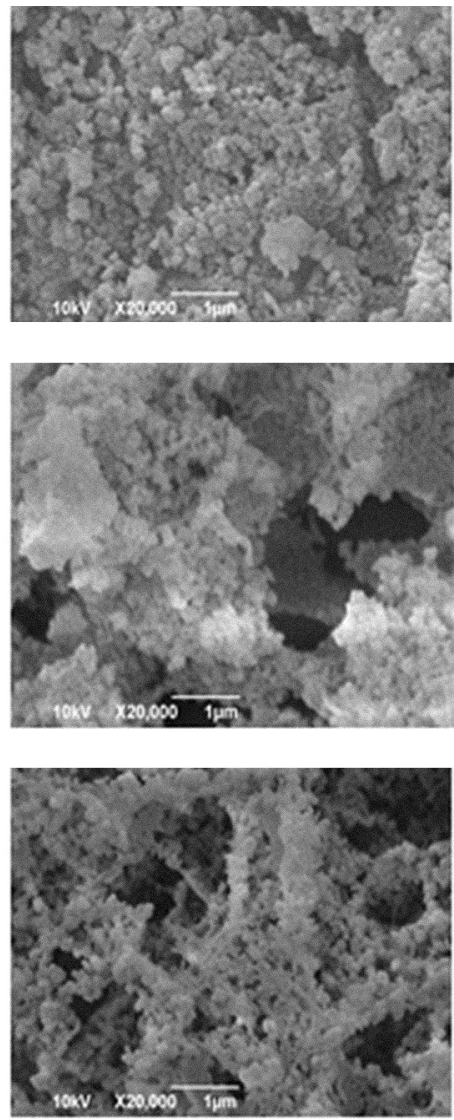

C

FIGURE 4. SEM micrographs of T1, T3 and T5 kajmak skin layers: 5,000x (a), 10,000x (b) and 20,000x (c) magnification levels

The microstructures of skin layers were generally characterised by the presence of gaps and protein matrix in the form of clusters with more or less stretched intertwined protein chains. Generally, the microstructures of skin layers resemble the microstructure of fermented dairy products (Kalab, 1979; Tamime et al., 2007), but some of them are closer to the microstructure of certain kinds of cheese: Cottage cheese (Glaser et al., 1979, 1980); Brick cheese (Kalab, 1979); Queso Blanco cheese (Kalab and Modler, 1985); Saint Paulin cheese (Rousseau, 1988); Acid-heat coagulated cheeses (Farkye, 2004); Panela type cheese-like product
(Lobato-Calleros et al., 2006); Malatya-Halloumi type of cheese (Hayaloglu et al., 2014); UF cheeses (Rodríguez et al., 1999; Miocinovic et al., 2012). The visible empty spaces (gaps and channels) in the microstructures of yoghurt and cheese were earlier occupied by serum and fat, and were removed due to sample preparation for SEM (Kalab et al., 1983; Lebeuf et al., 1998; Joshi et al., 2004). Positions in the cheese microstructure where milk fat droplets were present can also be characterised by spherical imprints of extracted fat in the continuous protein phase of cheese (Monteiro et al., 2009). 
C
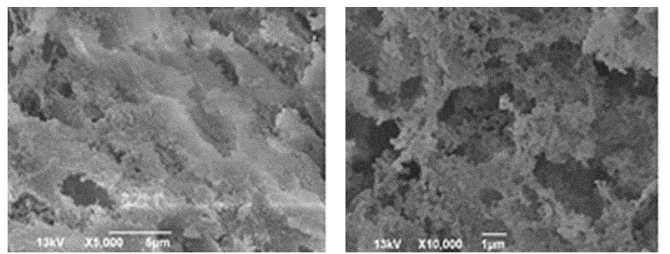

S1
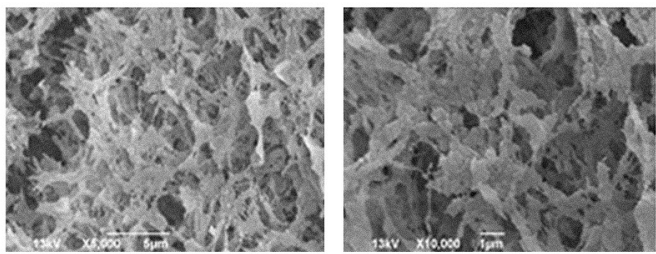

S2
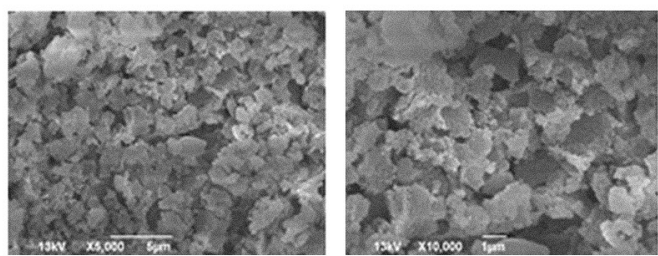

S3
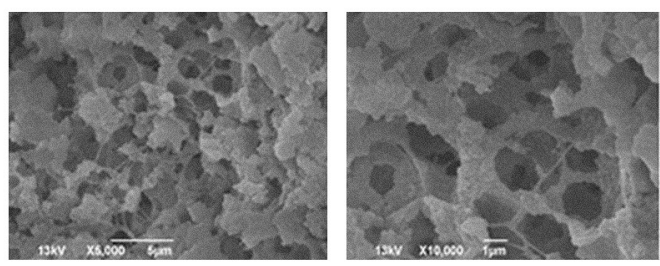

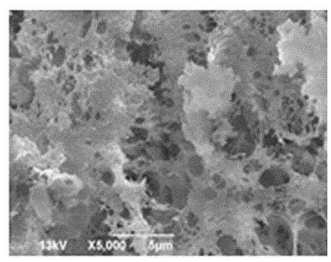

a

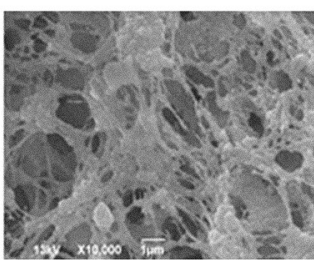

b
FIGURE 5. SEM micrographs of C, S1, S2, S3 and S4 kajmak skin layers: 5,000x (a) and 10,000x (b) magnification levels

The microstructures (Figure 4) of T1, T3 and T5 kajmak skin layer samples were obviously different. Distinct differences were observed between T1 on the one side, and samples produced from milk with more severe heat treatment, on the other. In the sample $T 1$ a very compact protein mass with a dense fused structure was observed, whereas a porous structure with relatively large pores was present in samples with severe heat treatments. By comparing sample $\mathrm{T} 1$ with samples T2-T5, it can be concluded that the stronger heat treatment contributed to the increased porosity of kajmak skin layer microstructure. At higher magnifications, the microstructure of sample T5 resembled the microstructure of yoghurt (Figure 4 b,c).

High heat treatment strongly influenced the kajmak skin layer microstructure. It is clear that $\beta$-LG denaturated by high heat treatment contributes to an increased protein incorporation, as well as to the formation of branched, filamentary structure evident in sample T5.

The aim of the S Series was to estimate the influence of milk composition on kajmak skin layer formation. It that respect, milk heat tretment was adjusted to the treatment which is usualy applied in traditional kajmak manufacture $\left(85^{\circ} \mathrm{C}\right.$ for $10 \mathrm{~min}$. folowed by $95^{\circ} \mathrm{C}$ for $10 \mathrm{~min}$.). The control sample (C) had a microstructure where rounded shapes were dominant (Figure 5). It is clearly evident that milk composition had an impact on the microstructure (Figure 5). The micrographs indicate that the higher fat level of kajmak skin layers, as well as the higher F/P ratio resulted in different kajmak skin layer structures which were generally more open and less dense compared to the control sample.

The presence of a very large amount of a fibrous type of structure (Figure 5) was observed in sample $\mathrm{S} 1$ derived from milk with a standard protein content $(3.4 \%)$ and significantly increased fat content (8\%). Sample $\mathrm{S} 1$ had a high fat and typical protein content, resulting in a high value of the F/P ratio (Table 4). Such F/P ratio indicated that the protein matrix was subjected to very large stretching, resulting in thiner and longer protein chains (Table 7).

TABLE 7. Minimum and maximum values of gap dimensions and thickness of chains $(\mu \mathrm{m})$ of the protein matrix in kajmak skin layers of S Series

\begin{tabular}{l|l|l|l|l|l}
\hline Skin layer & C & S1 & S2 & S3 & S4 \\
\hline Gaps & $0.92-4.92$ & $1.13-3.16$ & $1.89-3.56$ & $1.15-4.31$ & $1.00-3.81$ \\
\hline Chains & $0.57-2.42$ & $0.78-0.85$ & $0.50-3.20$ & $0.30-1.30$ & $0.18-0.80$ \\
\hline
\end{tabular}


In contrast to sample S1, sample S2 was made from milk with the standard fat content (4\%) and significantly elevated protein content (5\%), and had a significantly lower fat content $(P<0.05)$, resulting in a significant decrease of the $F / P$ ratio $(\mathrm{P}<0.01)$. Microstructure of sample S2 was characterised by dense and short protein matrix chains. Also, the microstructure looked very compact with a little jagged protein matrix, and could be described as a flake like structure (Figure 5), which resembles the microstructure of cheese.

In contrast to the control sample, kajmak skin layer obtained from the standard milk composition fortified with whey proteins (sample S3) had a microstructure with a large amount of stretched protein chains, of about $0.3 \mu \mathrm{m}$, resembling bridges connecting the gaps inside of the protein matrix (Table 7). The appearance of the ragged structure is probably the result of denatured whey proteins attached to the casein micelles surface, as reported in the case of yoghurt microstructure (Kalab et al., 1983).

The addition of whey proteins to milk with a high fat and protein content, (sample S4) resulted in the formation of a large number of filamentary matrix elements with the average thickness of about 0.2 $\mu \mathrm{m}-0.8 \mu \mathrm{m}$, which was similar to sample S1 with a high level of fat, but without added whey proteins (Figure 5). Since sample S4 had the lowest value of the F/P ratio, a compact microstructure of the protein matrix was expected. However, the incorporated whey proteins probably contributed to the formation of a very branched, stretched filamentary structure.

Similar phenomena were noticed in some types of cheese and yoghurt. Micrographs of UF cheeses showed the presence of a spongy structures of the protein network (as a consequence of high heat treatment of milk) which correspond to the denatured $\beta$-LG bound to k-casein (Rodríguez et al., 1999). Similarly, it was shown that the presence of denatured $\beta$-LG is necessary in yoghurt production for the development of filamentous microstructure, i.e. the development of "filamentous appendages" on the surface of casein micelles (Davies et al., 1978; Kalab et al., 1983; Mottar et al., 1989).

In contrast to cheese samples, the imprints of milk fat globules were not visible in the microstructures of kajmak skin layer samples. The absence of fat globule imprints is probably a consequence of the specificity of the kajmak formation process. More precisely, during the formation of the skin layer, milk fat is concentrated at the air-milk interface, due to surface tension (Pudja et al., 2008). Heat treatment of milk leads to significant changes of the surface tension of milk components, particularly whey proteins (Zayas, 1997). Also, it is likely that the components of MFGM as a surface-active compnentare partly desintegrated from the membrane (Kristensen et al., 1997), suggesting that some adsorption of the milk fat globule membrane fragments, as well as protein components at the interface between air and liquid, has occurred. Because of that, milk fat in kajmak probably participates partly in emulsified, and partly in deemulsified condition, i.e. in the form of free fats that impregnate other ingredients of the dry matter of kajmak (Pudja et al., 2006).

\section{Conclusion}

Whey proteins $\beta$-LG and a-LA in kajmak skin layer produced from common milk heat treatment were mainly presented in the form of disulfide-linked complexes of different molecular weights. The modified heat treatment $\left(75^{\circ} \mathrm{C}\right)$ caused the presence of $\beta$-LG in dominantly individual form. More severe treatments $\left(85^{\circ} \mathrm{C}, 90^{\circ} \mathrm{C}\right.$ and $95^{\circ} \mathrm{C}$ ) caused a full involvment of $\beta$-LG in kajmak skin layers in high molecular weight complexes formed on the disulfide bond basis.

The skin layer composition showed a very strong influence on its microstructure, which correlated well with the specificity of casein network formation, composition of the skin layers and the level of linked whey proteins. Dispersion and stretching of the protein matrix structure were in correlation with the amount of fat phase involved in kajmak skin layer composition. Reduction of the F/P ratio led to compact flake-like structures. Increase in the value of the F/P ratio caused a stretched type of protein structures, while reducing the thickness of protein chains. The linked $\beta$-LG changes the appearance of the skin layer microstructure and contributes to the formation of a very filamentary structure. 


\section{Acknowledgements}

This paper is a result of a research within Project No. 46009 financed by the Ministry of Education, Science and Technological Development of the Republic of Serbia.

\section{Ethical Statements}

Conflict of Interest: The authors declare that they do not have any conflict of interest.

Ethical Review: This study does not involve any human or animal testing.

\section{Mikrostruktura pokožica dobivenih tijekom proizvodnje kajmaka}

\section{Sažetak}

Kajmak je jedinstven mliječni proizvod s dugom tradicijom u balkanskim zemljama i na Bliskom istoku. Pokožice kajmaka su formirane tijekom 60 minuta proizvodnje kajmaka, što utječe na kvalitetu i određuje strukturu konačnog proizvoda. U radu je istražen utjecaj sastava mlijeka i toplinske obrade (75-95 $\left.{ }^{\circ} \mathrm{C} / 5 \mathrm{~min}\right)$ na sastav, mikrostrukturu i raspodjelu proteina u pokožicama kajmaka. Mikrostruktura je određena pomoću skenirajuće elektronske mikroskopije (SEM), dok je raspodjela proteinskih frakcija proučavana pomoću SDS PAGE elektoroforeze u reducirajućim i nereducirajućim uvjetima. Pokožice kajmaka dobivene iz mlijeka tretiranog u uobičajenom režimu intenzivne toplinske obrade, karakterizirane su s $\beta$-LG i a-LA prisutnim uglavnom u kompleksima povezanim disulfidnim vezama, dok je niža temperatura $\left(75^{\circ} \mathrm{C}\right)$ uzrokovala prisutnost proteina sirutke u dominantno pojedinačnom obliku. Jači tretmani mlijeka $\left(85^{\circ} \mathrm{C}, 90^{\circ} \mathrm{C}\right.$ i $95^{\circ} \mathrm{C}$ ) uzrokovali su potpuno uključivanje $\beta$-LG u komplekse, dok je određena količina a-LA pronađena kao monomer. Sastav pokožica, intenzitet primijenjene toplinske obrade mlijeka i agregirani proteini sirutke pokazali su vrlo jak utjecaj na mikrostrukturu pokožica. Mikrostruktura pokožica s niskim udjelom masti i omjerom F/P okarakterizirana je kompaktnom strukturom i zbijenim proteinskim matriksom. Visok udjel masti i omjer F/P rezultirali su dispergiranom mikrostrukturom s razvučenim proteinskim lancima. Mikrostrukture pokožica proizvedenih od mlijeka obogaćenog proteinima sirutke karakterizirane su vlaknastim, filamentoznim segmentima uslijed vezanih denaturiranih proteina sirutke, osobito vezanog $\beta$-LG.

\section{Ključne riječi: mikrostruktura, kajmak, pokožica, mliječna mast, mliječni proteini}


1. Akalin, S., Gönç, S., Ünal, G., Ökten, S. (2006):

Determination of some chemical and microbiological characteristics of Kaymak. Grasas y Aceites 57 (4), 429432.

2. Anema, S.G., McKenna, A.B. (1996): Reaction kinetics of thermal denaturation of whey proteins in heated reconstituted whole milk. Journal of Agricultural and Food Chemistry 44 (2), 422-428.

https://doi.org/10.1021/jf950217q

3. Anema, S.G. (2001): Kinetics of the irreversible thermal denaturation and disulfide aggregation of a-lactalbumin in milk samples of various concentrations. Journal of Food Science 66 (1), 2-9.

https://doi.org/10.1111/j.1365-2621.2001.tb15573.x

4. Anema, S.G., Li, Y. (2003): Association of denatured whey proteins with casein micelles in heated reconstituted skim milk and its effect on casein micelle size. Journal of Dairy Research 70 (1), 73-83. https://doi.org/10.1017/S0022029902005903

5. Atamer, M., Senell, E., Hayaloğlu, A., Özer, B. (2016): Kuru Kaymağın Tekstürel Yapısı. Akademik Gida 14 (2), 189195.

6. Cakmakci, S., Hayaloglu, A.A. (2011): Evaluation of the chemical, microbiological and volatile aroma characteristics of Ispir Kaymak, a traditional Turkish dairy product. International Journal of Dairy Technology 64(3), 444-450.

https://doi.org/10.1111/j.1471-0307.2011.00687.x

7. Corredig, M., Dalgleish, D.G. (1996a): Effect of temperature and $\mathrm{pH}$ on the interactions of whey proteins with casein micelles in skim milk. Food Research International 29 (1), 49-55.

https://doi.org/10.1016/0963-9969(95)00058-5

8. Corredig, M., Dalgleish, D.G. (1996b): Effect of different heat treatments on the strong binding interactions between whey proteins and milk fat globules in whole milk. Journal of Dairy Research 63 (3), 441-449. https://doi.org/10.1017/S0022029900031940

9. Corredig, M., Dalgleish, D.G. (1999): The mechanisms of heat-induced interactions of whey proteins with casein micelles in milk. International Dairy Journal 9 (3-6), 233236.

https://doi.org/10.1016/S0958-6946(99)00066-7

10. Dannenberg, F., Kessler, H.-G. (1988): Reaction kinetics of the denaturation of whey proteins in milk. Journal of Food Science, 53 (1), 258-263. https://doi:10.1111/j.1365-2621.1988.tb10223.x

11. Davies, F.L., Shankar, P.A., Brooker, B.E., Hobbs, D.G. (1978): A heat-induced change in the ultrastructure of milk and its effect on gel formation in yoghurt. Journal of Dairy Research 45 (1), 53-58. https://doi.org/10.1017/S0022029900016198

12. Dozet, N., Adzic, N., Stanisic, M., Zivic, N. (1996): Autochthonous dairy products, Agriculture Institute, Podgorica, Montenegro, 131-149.

13. Djerovski, J., Radulovic, Z., Radin, D., Radovanovic, M., Pudja, P. (2006): The investigation of kajmak quality: chemical, microbiological and sensory aspects, Food industry-Milk and dairy products 17 (1-2), 25-29.
14. Ecim-Djuric, O., Radovanovic, M., Nedeljkovic, A., Miocinovic, J., Pudja, P. (2012): Influence of air velocity on the mass balance in the initial stage of kajmak formation. Proccedings of " 43 rd International congress \& exhibition on heating, refrigeration and air conditioning" Belgrade, 5-7. XII 2012, 135-143.

15. Ecim-Djuric, O., Radovanovic, M., Nedejkovic, A., Miocinovic, J., Pudja, P. (2013): Influence of air temperature and relative humidity in the hot phase of kajmak formation. Proccedings "The First International Symposium on Agricultural Engineering” ISAE-2013. $4^{\text {th }}-6^{\text {th }}$ October, Belgrade, Zemun, Serbia, IV 65-74. http:// www.isae.agrif.bg.ac.rs

16. Ecim-Djuric, O., Radovanovic, M., Nedejkovic, A., Miocinovic, J., Pudja, P. (2017): Determination of optimal parameters of the moist air boundary layer flow relevant for the Initial period of continual processof kajmak formation. Proceedings of the International HVAC\&R Congress Belgrade, sep. 2017, 45 (1), 1-5. https://izdanja.smeits.rs/index.php/kghk/article/view/2869

17. Farkye, N.Y. (2004): Acid-and Acid/Rennet-curd Cheeses. Part C: Acid-heat coagulated cheeses. Cheese: Chemistry, Physics and Microbiology, Third edition. Vol.2: Major Cheese Groups, 343-348. Edited by: Patric, F. Fox, Paul L.H. MCSweeney, Timothy M. Cogan and Timothy P. Guinee. ISBN:0-1226-3653-8. Sci ISBN: 0-1226-3653-1

18. Glaser, J., Carroad, P.A., Dunkley, W.L. (1979): Surface structure of cottage cheese curd by electron microscopy. Journal of Dairy Science 62 (7), 1058-1068. https://doi.org/10.3168/jds.S0022-0302(79)83375-5.

19. Glaser, J., Carroad, P.A., Dunkley, W.L. (1980): Electron microscopic studies of casein micelles and curd microstructure in Cottage Cheese. Journal of Dairy Science 63 (1), 37-48. https://doi.org/10.3168/jds.S0022-0302(80)82885-2.

20. Hayaloglu, A.A., Karatekin, B., Gurkan, H (2014): Thermal stability of chymosin or microbial coagulant in the manufacture of Malatya, a Halloumi type cheese: Proteolysis, microstructure and functional properties. International Dairy Journal 38 (2), 136-144. https://doi.org/10.1016/j.idairyj.2014.04.001

21. IDF (1986): Cheese, Determination of fat content Van Gulik butyrometers method. IDF Standard 5B. International Dairy Federation, Brussels, Belgium.

22. IDF (2002): Milk. Determination of Nitrogen Content. IDF Standard 20B. International Dairy Federation, Brussels, Belgium.

23. Joshi, N.S., Muthukumarappan, K., Dave, R.I. (2004): Effect of calcium on microstructure and meltability of part skim Mozzarella cheese. Journal of Dairy Science 87 (7), 1975-1985. https://doi.org/10.3168/jds.S0022-0302(04)70014-4

24. Kalab, M (1979): Microstructure of dairy food. 1. Milk product based on protein. Journal of Dairy Science 62 (8), 1352-1364.

https://doi.org/10.3168/jds.S0022-0302(79)83424-4

25. Kalab, M., Allan-Wojtas, P., Phipps-Todd, B. (1983):

Development of microstructure of set-style nonfat yogurt - a review, Journal of Food Structure 2 (1), 51-66. 
26. Kalab, M., Modler, W.H. (1985): Development of microstructure in a Cream cheese based on Queso Blanco cheese. Journal of Food Structure 4 (1), 89-98.

27. Kristensen, D., Jensen, P.Y., Madsen, F., Birdi, K.S. (1997): Rheology and surface tension of selected processed dairy fluids: Influence of temperature. Journal of Dairy Science 80 (10), 2282-2290. https://doi.org/10.3168/jds.S0022-0302(97)76177-0

28. Laemmli, U.K. (1970): Cleavage of strucutural properties during the assembly of the head of bacteriophage T4. Nature 227, 680-685.

29. Lebeuf, Y., Lacroix, C., Paquin, P. (1998): Effet de l'incorporation des protéines du lactosérum dénaturées et microparticulées dans le cheddar jeune. Le Lait 78, 303-318. https://doi.org/10.1051/lait:1998331

30. Lobato-Calleros, C., Ramos-Solís, L., Santos-Moreno, A., Rodríguez-Huezo, M.E. (2006): Microstructure and texture of panela type cheese-like products: use of low methoxyl pectin and canola oil as milk-fat substitutes. Revista Mexicana de Ingenieria quimica 5 (1), 71-79.

31. Lyster, R. L. J. (1970): The denaturation of $\beta$-lactalbumin and a-lactoglobulin in heated milk. Journal of Dairy Research 37 (2), 233-243. https://doi.org/10.1017/S0022029900013297.

32. Miocinovic, J., Radulovic, Z., Miloradovic, Z., Trpković, G., Pesic Mikulec, D., Pavlovic, V., Pudja, P. (2012): Influence of autochtonous lactic acid bacteria on the proteolysis, microstructure and sensory properties of low fat UF cheeses during ripening. Mljekarstvo 62 (2), 126-135.

33. Monteiro, R.R., Tavares, D.Q., Kindstedt, P.S., Gigante, M.L. (2009): Effect of pH on microstructure and characteristics of cream cheese. Journal of Food Science 74 (2), 112-117. https://doi.org/10.1111/j.1750-3841.2008.01037.x

34. Mottar, J., Bassier, A., Joniau, M., Baert, J. (1989). Effect of heatinduced association of whey proteins and casein micelles on yogurt texture. Journal of Dairy Science 72 (9), 2247-2256. https://doi.org/10.3168/jds.S0022-0302(89)79355-3

35. Petit, J., Herbig, A.L., Moreau, J.F., Le Page, J.F., Six, T., Delaplace, G. (2012): Granulomorphometry: A sutible tool for identifying hydrophobic and disulfide bonds in $\beta$-lactoglobulin aggregates. Aplication to the study of $\beta$-lactoglobulin aggregation mechanism between 70 and $95{ }^{\circ} \mathrm{C}$. Journal of Dairy Science 95 (8), 4188-4202. https://doi.org/10.3168/jds.2011-4146

36. Pudja, P., Radovanovic, M., Djerovski, J. (2005a): A study on kajmak classification and characteristics. Journal of Food industry-Milk and dairy products, 16 (1-2), 55-60.

37. Pudja, P., Radovanovic, M., Starcevic V., Miocinovic J. (2005b): Kajmak composition and characteristics. I. Influence of milk composition on skin formation. Biotechnology in Animal Husbandry (21) 175-187.

38. Pudja, P., Radovanovic, M., Djerovski, J. (2006): Production and charasteristics of kajmak. Mljekarstvo 56 (4), 221 232.
39. Pudja, P., Djerovski, J., Radovanovic, M. (2008): An autochthonous Serbian product-Kajmak Characteristics and production procedures. Journal of Dairy Science $\odot$ Technology 88 (2), 163-172. https://doi.org/10.1051/dst:2007023

40. Radovanovic, M., Nedeljkovic, A., Trpkovic, G., Miocinovic, J., Pudja, P.(2012a): Influence of milk composition on the initial stage of kajmak formation, Proceeding of Papers of The first international symposium on animal science Book II, 8-10 November 2012, Belgrade, 1042-1049.

41. Radovanovic, M., Nedeljkovic, A., Trpkovic, G., Miocinovic, G., Pudja, P. (2012b): The signifacance of whey proteins in kajmak formation, Book of Abstracts of The $40^{\text {th }}$ Croatian dairy experts symposium, 21-24 October, Lovran, 82-83. ISSN 1847-1870.

42. Radovanovic, M., Nedeljkovic, A., Bogdanovic, M., Miocinovic, J., Pudja, P. (2013): Composition and protein distribution of top and lower layers of kajmak. In Proceedings of the $24^{\text {th }}$ International Scientific-ExpertConference of Agriculture and Food Industry, Sarajevo, Bosnia and Herzegovina, 25-28 September 2013, 171 175.

43. Radovanovic, M., Nedeljkovic, A., Miocinovic, J., Pavlovic, V., Pudja, P. (2014): Influence of milk fat and protein levels on composition and microstructure of skin layers in kajmak formation, Book of Abstracts of The $2^{\text {nd }}$ International Congress on Food Technology, November 05-07, 2014 Kusadasi/Turkey, 202.

44. Rodríguez, J., Requena,T., Fontecha, J., Goudédranche,H., Juárez, M. (1999): Effect of different membrane separation technologies (ultrafiltration and microfiltration) on the texture and microstructure of semihard low-fat cheeses. Journal of Agricultural and Food Chemistry 47 (2), 558-565.

https://doi.org/10.1021/jf9805597

45. Rousseau, M. (1988): Changes in the microstructure of Saint Paulin cheese during manufacture studied by scanning electron microscopy. Journal of Food Structure 7 (1), 105-113.

46. Tamime, A.Y, Hassan,A., Farnworth, E., Toba, T. (2007): Structure of Fermented Milks. Structure of Dairy Products, 134-169. Edited by Dr Adnan Tamime. Copyright ${ }^{\circ} 2007$ by Blackwell Publishing Ltd ISBN-13: 978-1-4051-29756

47. Ye, A., Singh, H., Taylor, M.W., Anema, S. (2004): Interaction of whey proteins with milk fat globule membrane proteins during heat treatment of whole milk. Le Lait. 84 (3), 269-283. https://doi.org/10.1051/lait:2004004

48. Zayas, J.F. (1997): Emulsifying properties of proteins: In J. F. Zayas (Ed.), Functionality of Proteins in Food (chapter 3, pp. 134-227). Springer-Verlag Berlin Heidelberg 1997. 